Article

\title{
Screening and Identification of the Metabolites in Rat Plasma and Urine after Oral Administration of Areca catechu L. Nut Extract by Ultra-High-Pressure Liquid Chromatography Coupled with Linear Ion Trap-Orbitrap Tandem Mass Spectrometry
}

\author{
Lulu Li ${ }^{1, \dagger}$, Zhiqiang Luo ${ }^{1, \dagger}$, Yang Liu ${ }^{1, *}$, Hao Wang ${ }^{1}$, Aoxue Liu ${ }^{1}$, Guohua Yu ${ }^{1}$, Mengwei Li ${ }^{1}$, \\ Ruirui Yang ${ }^{1}$, Xinjing Chen ${ }^{1}$, Jialian Zhu ${ }^{1}$ and Baosheng Zhao ${ }^{2, *}$ \\ 1 School of Chinese Materia Medica, Beijing University of Chinese Medicine, No. 6, Zhonghuan South Road, \\ Wangjing, Chaoyang District, Beijing 100102, China; lulu130901@126.com (L.L.); lzq4y3r@126.com (Z.L.); \\ adopus@126.com (H.W.); axljiayoula@163.com (A.L.); sufei_sophie@163.com (G.Y.); \\ 20160931848@bucm.edu.cn (M.L.); yangrr5021@126.com (R.Y.); chxj9208@sina.com (X.C.); \\ zhujialian2013@126.com (J.Z.) \\ 2 Research Institute of Chinese Medicine, Beijing University of Chinese Medicine, No. 11, \\ North Third Ring Road, Chaoyang District, Beijing 100029, China \\ * Correspondence: liuyang@bucm.edu.cn (Y.L.); zhaobs1973@163.com (B.Z.); \\ Tel./Fax: +86-010-8473-8611 (Y.L.); +86-010-6428-6295 (B.Z.) \\ + These authors contributed equally to this work.
}

Received: 6 June 2017; Accepted: 19 June 2017; Published: 21 June 2017

\begin{abstract}
Areca catechu L. nut, a well-known toxic traditional herbal medicine, has been widely used to treat various diseases in China and many other Asian countries for centuries. However, to date the in vivo absorption and metabolism of its multiple bioactive or toxic components still remain unclear. In this study, liquid chromatography coupled with tandem mass spectrometry was used to analyze the major components and their metabolites in rat plasma and urine after oral administration of Areca catech $u$ L. nut extract (ACNE). A total of 12 compounds, including 6 alkaloids, 3 tannins and 3 amino acids, were confirmed or tentatively identified from ACNE. In vivo, 40 constituents, including 8 prototypes and 32 metabolites were identified in rat plasma and urine samples. In summary, this study showed an insight into the metabolism of ACNE in vivo, which may provide helpful chemical information for better understanding of the toxicological and pharmacological profiles of ACNE.
\end{abstract}

Keywords: Areca catechu L.; major compounds; metabolites; UHPLC-LTQ-Orbitrap

\section{Introduction}

Traditional Chinese medicine (TCM) has played an important role in preventing or treating a variety of complicated diseases over thousands of years [1-3]. It is extensively accepted that the therapeutic or toxic effect of TCM results from the prototype components and/or their metabolites $[4,5]$. However, profiling the absorbed components and metabolites of an herbal medicine in vivo is always a great challenge [6]. Metabolites exist in a variety of forms and are usually present at trace levels; therefore, the signals from the metabolites are often masked by background noise from endogenous interference [7]. Owing to its high selectivity and sensitivity, liquid chromatography coupled with tandem mass spectrometry (LC-MS/MS) has been extensively used in drug metabolism studies. LC-MS/MS combined with sophisticated software tools can offer abundant structural information and accurate mass measurement for both precursor and product ions, which represents a powerful and reliable analytical technique to detect and identify unknown metabolites in complex matrixes [8-12]. 
Areca catechu L. one of most popular medicinal herbs, is widely distributed in the south of China. The nut of Areca catechu L. has been recorded in the pharmacopoeia of China for the treatment of parasitic diseases, dyspepsia, abdominal pain, etc. [13]. Modern pharmacological studies and clinical practice revealed that Areca catechu L. nut shows a variety of pharmacological functions, including wound healing [14], anti-migraine effect [15], anti-depressant effect [16], and hypoglycemic [17] and antioxidant effects [18]. As a toxic herbal medicine, Areca catechu L. nut also has some potential toxicities, such as decline of sperm count sand motility and induction of substantial abnormalities [19,20]. Although many reports regarding the pharmacological activities and potential toxicities have been published as described above, very little is known about its absorbed components and metabolites in vivo.

Hence, the overall objective of this research was to investigate in detail the in vivo absorption and metabolism of Areca catechu L. nut extract (ACNE). As we all know, plasma and urine are recognized as ideal biological matrices in drug absorption and metabolism studies [21,22]. In this work, a total of 26 components in the plasma and 31 components in the urine were characterized by ultra-high-pressure liquid chromatography coupled with linear ion trap-Orbitrap tandem mass spectrometry (UHPLC-LTQ-Orbitrap). From the results, we can know the probable metabolic pathways of chemical constituents in ACNE. To the best of our knowledge, this is the first study on screening the multiple absorbed and metabolic components of ACNE in vivo, which could provide a scientific basis for explaining the curative and toxicological mechanism of ACNE.

\section{Results and Discussion}

\subsection{Identification of the Major Components in ACNE by UHPLC-LTQ-Orbitrap}

A total of 12 compounds were separated and identified according to the retention time, obtained mass spectra, and by comparing with data from literature and standard sample. All of them were attributed to three types, including 6 alkaloids, 3 tannins and 3 amino acids. Detailed identified information is listed in Table 1. The detailed extracted ion chromatography of ACNE is shown in Figure 1 and Figure S1 in the Supplemental material. The structures of the 12 compounds are shown in Figure 2.

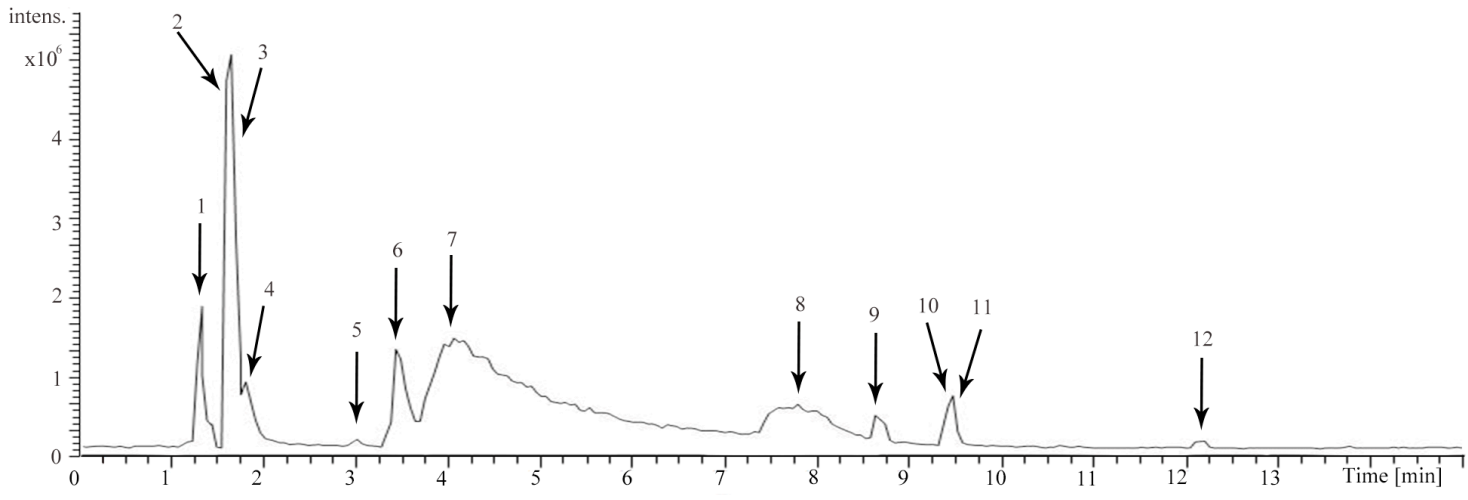

Figure 1. Extracted ion chromatogram of Areca catechu L. nut extract (ACNE) in positive ion mode. 
<smiles>CC(C)[C@H](N)C(=O)O</smiles><smiles>O=C(O)C1=CCCNC1</smiles><smiles>O=C(O)C1=CCNCC1</smiles><smiles>COC(=O)C1CCCNC1</smiles>

Peak 4<smiles>COC(=O)C1=CCCN(C)C1</smiles>

Peak 7
Peak 2<smiles>N[C@@H](Cc1ccc(O)cc1)C(=O)O</smiles>

Peak 5<smiles>COC1=C(OC)CN(C)C=C1</smiles>

Peak 8<smiles>CN1CCC=C(C(=O)O)C1</smiles>

Peak 3<smiles>COC(=O)C1=CCCNC1</smiles><smiles>NC(Cc1c[nH]c2ccccc12)C(=O)O</smiles>

Peak 9<smiles>Oc1cc(O)c2c(c1)O[C@H](c1ccc(O)c(O)c1)[C@H](O)C2</smiles><smiles>Oc1cc(O)c2c(c1)O[C@H](c1ccc(O)c(O)c1)[C@H](O)C2</smiles>

Peak 10 or 12<smiles>Oc1cc(O)c2c(c1)OC(c1ccc(O)c(O)c1)C(O)C2c1c(O)cc(O)c2c1OC(c1ccc(O)c(O)c1)C(O)C2</smiles>

Peak 11

Figure 2. The structures of the 12 compounds. 
Table 1. The mass spectral data of components observed by UHPLC-LTQ-Orbitrap.

\begin{tabular}{|c|c|c|c|c|c|c|}
\hline Component & $t_{\mathrm{R}}(\mathrm{Min})$ & {$[\mathrm{M}+\mathrm{H}]^{+}$Ion $(m / z)$} & Error (ppm) & Formula & Fragment Ions $(\mathrm{m} / \mathrm{z})$ & Identification \\
\hline 1 & 1.36 & 118.0861 & -1.568 & $\mathrm{C}_{5} \mathrm{H}_{11} \mathrm{NO}_{2}$ & 72.0806 & Valine \\
\hline 2 & 1.70 & 128.0705 & -0.743 & $\mathrm{C}_{6} \mathrm{H}_{9} \mathrm{NO}_{2}$ & $110.0601,81.0334$ & Guvacine/Isoguvacine \\
\hline 3 & 1.74 & 142.0862 & -0.085 & $\mathrm{C}_{7} \mathrm{H}_{11} \mathrm{NO}_{2}$ & $128.0745,124.0758,96.0807,81.0333$ & Arecaidine \\
\hline 4 & 1.87 & 144.1018 & -0.869 & $\mathrm{C}_{7} \mathrm{H}_{13} \mathrm{NO}_{2}$ & $126.0915,114.0913,84.0806$ & Methyl piperidine-3-carboxylate \\
\hline 5 & 3.05 & 182.0810 & -0.822 & $\mathrm{C}_{9} \mathrm{H}_{11} \mathrm{NO}_{3}$ & $165.0548,136.0760$ & Tyrosine \\
\hline 6 & 3.47 & 142.0862 & -0.115 & $\mathrm{C}_{7} \mathrm{H}_{11} \mathrm{NO}_{2}$ & $113.9638,110.0602,81.0334$ & Guvacoline \\
\hline 7 & 4.09 & 156.1018 & -0.115 & $\mathrm{C}_{8} \mathrm{H}_{13} \mathrm{NO}_{2}$ & $124.0757,113.0597,96.0807,81.0333$ & Arecoline \\
\hline 8 & 7.81 & 156.1017 & -0.255 & $\mathrm{C}_{8} \mathrm{H}_{13} \mathrm{NO}_{2}$ & $128.1069,113.0597,81.0333$ & Arecolidine \\
\hline 9 & 8.68 & 579.1489 & -1.334 & $\mathrm{C}_{30} \mathrm{H}_{26} \mathrm{O}_{12}$ & $453.1197,427.1039,409.0937,291.0874$ & Procyanidin B2 \\
\hline 11 & 9.53 & 205.0970 & -0.996 & $\mathrm{C}_{11} \mathrm{H}_{12} \mathrm{~N}_{2} \mathrm{O}_{2}$ & $188.0917,159.9331$ & Tryptophan \\
\hline 12 & 12.20 & 291.0860 & -0.978 & $\mathrm{C}_{15} \mathrm{H}_{14} \mathrm{O}_{6}$ & $273.0764,165.0549,151.0393,139.0393,123.0444$ & Epicatechin (EC) \\
\hline
\end{tabular}




\subsubsection{Alkaloids}

Component 7 (4.09 $\mathrm{min},-0.115 \mathrm{ppm})$ showed the accurate $[\mathrm{M}+\mathrm{H}]^{+}$ion at $m / z 156.1018$ and produced the characteristic ions at $m / z 124.0757\left[\mathrm{M}+\mathrm{H}-\mathrm{OCH}_{3}-\mathrm{H}_{2}\right]^{+}, 113.0597\left[\mathrm{M}+\mathrm{H}_{-} \mathrm{C}_{2} \mathrm{H}_{5} \mathrm{~N}\right]^{+}$, $96.0807\left[\mathrm{M}+\mathrm{H}-\mathrm{C}_{2} \mathrm{H}_{4} \mathrm{O}_{2}\right]^{+}$and $81.0333\left[\mathrm{M}+\mathrm{H}-\mathrm{C}_{2} \mathrm{H}_{4} \mathrm{O}_{2}-\mathrm{CH}_{3}\right]^{+}$. By comparing with the reference compound and the literature data [23], component 7 was identified as arecoline. The proposed fragmentation pathway of arecoline is shown in Figure 3a.
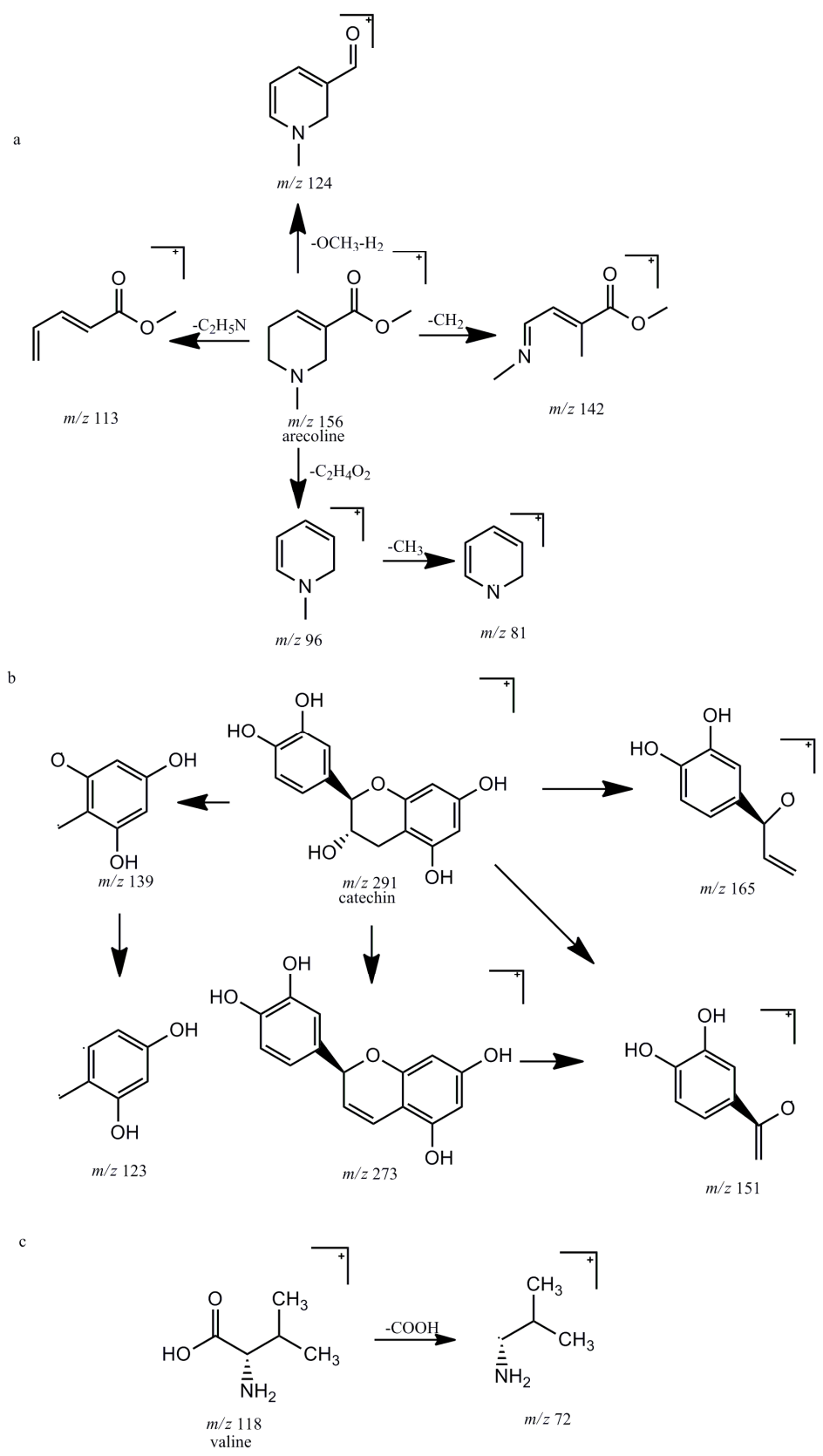

Figure 3. The proposed fragmentation pathways of arecoline (a); catechin (b) and valine (c) in positive ion mode.

Component 8 (7.81 $\mathrm{min},-0.255 \mathrm{ppm})$ displayed the molecular ion at $m / z$ 156.1017. Moreover, it exhibited three major ions at $m / z 128.1069\left[\mathrm{M}+\mathrm{H}-2 \mathrm{CH}_{3}\right]^{+}, 113.0597\left[\mathrm{M}+\mathrm{H}-3 \mathrm{CH}_{3}\right]^{+}$and 81.0333 $\left[\mathrm{M}+\mathrm{H}-2 \mathrm{OCH}_{3}-\mathrm{CH}_{3}\right]^{+}$. Accordingly [24], component 8 was tentatively identified as arecolidine. 
Component 2 (1.70 $\mathrm{min},-0.743 \mathrm{ppm})$ provided the $[\mathrm{M}+\mathrm{H}]^{+}$ion at $\mathrm{m} / z$ 128.0705, which led to two major product ions at $m / z 110.0601\left[\mathrm{M}+\mathrm{H}-\mathrm{H}_{2} \mathrm{O}\right]^{+}$and $81.0334\left[\mathrm{M}+\mathrm{H}-\mathrm{COOH}-\mathrm{H}_{2}\right]^{+}$. In accordance with the literature data [25], component 2 was tentatively confirmed as guvacine or its isomer, isoguvacine.

Component 3 (1.74 $\mathrm{min},-0.085 \mathrm{ppm}$ ) exhibited the molecular ion at $m / z 142.0862$. It gave rise to four fragment ions at $m / z 128.0745\left[\mathrm{M}+\mathrm{H}-\mathrm{CH}_{2}\right]^{+}, 124.0758\left[\mathrm{M}+\mathrm{H}_{-} \mathrm{H}_{2} \mathrm{O}\right]^{+}, 96.0807\left[\mathrm{M}+\mathrm{H}_{-} \mathrm{CH}_{2} \mathrm{O}_{2}\right]^{+}$ and $81.0333\left[\mathrm{M}+\mathrm{H}-\mathrm{CH}_{2} \mathrm{O}_{2}-\mathrm{CH}_{3}\right]^{+}$. According to the literature data [26], component 3 was identified as arecaidine.

Component 6 (3.47 $\mathrm{min},-0.115 \mathrm{ppm}$ ) also showed the molecular ion at $\mathrm{m} / \mathrm{z} 142.0862$ which was a 14-Da $\left(\mathrm{CH}_{2}\right)$ loss of component 7. Meanwhile, component 6 produced fragment ions at $m / z 113.9638$ $\left[\mathrm{M}+\mathrm{H}-\mathrm{CH}_{3} \mathrm{~N}\right]^{+}, 110.0602\left[\mathrm{M}+\mathrm{H}-\mathrm{OCH}_{3}-\mathrm{H}_{2}\right]^{+}$and $81.0334\left[\mathrm{M}+\mathrm{H}-\mathrm{C}_{2} \mathrm{H}_{4} \mathrm{O}_{2}\right]^{+}$. By comparing with the reference compound and the literature data [25], component 6 was confirmed as guvacoline.

Component 4 (1.87 $\mathrm{min},-0.869 \mathrm{ppm})$ yielded molecular ion at $m / z$ 144.1018. Moreover, it showed major fragment ions at $m / z 126.0915\left[\mathrm{M}+\mathrm{H}-\mathrm{CH}_{3}-\mathrm{H}_{2}\right]^{+}, 114.0913\left[\mathrm{M}+\mathrm{H}-\mathrm{CH}_{3} \mathrm{~N}^{+}\right.$and 84.0806 $\left[\mathrm{M}+\mathrm{H}-\mathrm{C}_{2} \mathrm{H}_{4} \mathrm{O}_{2}\right]^{+}$. Thus, component 4 was tentatively identified as methyl piperidine-3-carboxylate.

\subsubsection{Tannins}

Component 10 (9.48 $\mathrm{min},-0.669 \mathrm{ppm})$ and component 12 (12.20 $\mathrm{min},-0.978 \mathrm{ppm})$ showed the same $[\mathrm{M}+\mathrm{H}]^{+}$ion at $m / z 291.0861$, and both of them produced the same fragment ions at $m / z 273.0762$ $\left[\mathrm{M}+\mathrm{H}-\mathrm{H}_{2} \mathrm{O}\right]^{+}, 165.0548\left[\mathrm{M}+\mathrm{H}-\mathrm{C}_{6} \mathrm{H}_{6} \mathrm{O}_{3}\right]^{+}, 151.0392\left[\mathrm{M}+\mathrm{H}-\mathrm{C}_{7} \mathrm{H}_{7} \mathrm{O}_{3}\right]^{+}, 139.0392\left[\mathrm{M}+\mathrm{H}-\mathrm{C}_{8} \mathrm{H}_{7} \mathrm{O}_{3}\right]^{+}$ and $123.0443\left[\mathrm{M}+\mathrm{H}-\mathrm{C}_{8} \mathrm{H}_{7} \mathrm{O}_{3}-\mathrm{OH}\right]^{+}$. According to the literature data [27], they were tentatively designated as catechin $(\mathrm{C})$ and epicatechin $(\mathrm{EC})$, respectively. The proposed fragmentation pathway of catechin is shown in Figure $3 b$.

Compound 9 (8.68 $\mathrm{min},-1.334 \mathrm{ppm})$ exhibited the $[\mathrm{M}+\mathrm{H}]^{+}$ion at $m / z 579.1489$, and gave rise to four major product ions at $m / z 453.1197,427.1039,409.0937$ and 291.0874. The fragment ion at $m / z$ 409.0937 was generated through the loss of $\mathrm{H}_{2} \mathrm{O}$ from the ion at $m / z 427.1039$; the fragment ion at $m / z$ 427.1039 was attributed to the retro Diels-Alder (RDA). The ion at $m / z 291.0874\left[\mathrm{M}+\mathrm{H}-\mathrm{C}_{15} \mathrm{H}_{13} \mathrm{O}_{6}\right]^{+}$ was a prototype losing an aggregate unit. According to the literature data [28], component 9 was tentatively characterized as procyanidin B2.

\subsubsection{Amino Acid}

Component 1 (1.36 min, $-1.568 \mathrm{ppm})$ displayed the molecular ion at $m / z 118.0861$ which led the major product ion at $m / z 72.0806[\mathrm{M}+\mathrm{H}-\mathrm{HCOOH}]^{+}$. By comparing with the reference compound, component 1 was identified as valine. The proposed fragmentation pathway of valine is shown in Figure 3c.

Compound 5 (3.05 $\mathrm{min},-0.822 \mathrm{ppm}$ ) exhibited $[\mathrm{M}+\mathrm{H}]^{+}$ion at $m / z 182.0810$ and the main fragment ions of it were at $m / z 165.0548$ and 136.0760. The former ion at $m / z 165.0548$ was produced from the neutral loss of $\mathrm{NH}_{3}$, and the latter ion at $m / z 136.0760$ was generated through the loss of $\mathrm{HCOOH}$ from the molecular ion. Hence, compound 5 was tentatively identified as tyrosine.

Compound $11(9.53 \mathrm{~min},-0.996 \mathrm{ppm})$ showed the $[\mathrm{M}+\mathrm{H}]^{+}$ion at $m / z 205.0970$ and it yielded

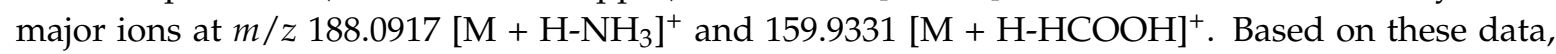
component 11 was tentatively assigned as tryptophan.

\subsection{Identification of the Major Metabolites in ACNE by UHPLC-LTQ-Qrbitrap}

The identification of the compounds in rat urine and plasma were also performed by UHPLC-LTQ-Qrbitrap. Altogether, 40 compounds, including 8 prototype and 32 metabolites were identified by comparing the retention time and the mass data (Table 2). Among them, 31 of them were from rat urine while 26 were from rat plasma. Detailed extracted ion chromatograms of the urine sample are shown in Figure 4, and the plasma sample are shown in Figure 5. In addition, the metabolic pathways of catechin (C) and arecoline are summarized in Figure 6. 
Table 2. The mass spectral data of metabolites observed by UHPLC-LTQ-Orbitrap.

\begin{tabular}{|c|c|c|c|c|c|c|c|c|}
\hline Metabolite & $\begin{array}{c}t_{\mathrm{R}} \\
\text { (Min) }\end{array}$ & $\begin{array}{l}\text { Selected } \\
\text { Ion }\end{array}$ & $\begin{array}{l}\text { Calculated } \\
\text { Mass }(\mathrm{m} / \mathrm{z})\end{array}$ & $\begin{array}{l}\text { Error } \\
\text { (ppm) }\end{array}$ & Formula & Fragmentation & Identification & Source \\
\hline M1 & 1.75 & {$[\mathrm{M}+\mathrm{H}]^{+}$} & 128.0706 & -0.352 & $\mathrm{C}_{6} \mathrm{H}_{9} \mathrm{NO}_{2}$ & $110.0601,81.0332$ & Guvacine/Isoguvacine & Urine; Plasma \\
\hline M2 & 1.76 & {$[\mathrm{M}+\mathrm{H}]^{+}$} & 142.0862 & -0.740 & $\mathrm{C}_{7} \mathrm{H}_{11} \mathrm{NO}_{2}$ & $124.0759,96.0809,81.0334$ & Arecaidine & Urine; Plasma \\
\hline M3 & 1.78 & {$[\mathrm{M}+\mathrm{H}]^{+}$} & 144.1018 & -0.661 & $\mathrm{C}_{7} \mathrm{H}_{13} \mathrm{NO}_{2}$ & $126.0915,114.0915,84.0806$ & Methyl piperidine-3-carboxylate & Urine; Plasma \\
\hline M4 & 1.96 & {$[\mathrm{M}+\mathrm{H}]^{+}$} & 158.0811 & -0.315 & $\mathrm{C}_{7} \mathrm{H}_{11} \mathrm{NO}_{3}$ & $140.0529,112.0870$ & Arecaidine $\mathrm{N}$-oxide & Urine; Plasma \\
\hline M5 & 3.28 & {$[\mathrm{M}+\mathrm{H}]^{+}$} & 142.0862 & -0.388 & $\mathrm{C}_{7} \mathrm{H}_{11} \mathrm{NO}_{2}$ & $113.0597,110.0601,81.0333$ & Guvacoline & Urine; Plasma \\
\hline M6 & 3.58 & {$[\mathrm{M}+\mathrm{H}]^{+}$} & 156.1018 & -0.418 & $\mathrm{C}_{8} \mathrm{H}_{13} \mathrm{NO}_{2}$ & $124.0758,113.0598,96.0807,81.0333$ & Arecoline & Urine \\
\hline M7 & 4.31 & {$[\mathrm{M}+\mathrm{H}]^{+}$} & 319.1319 & -1.000 & $\mathrm{C}_{13} \mathrm{H}_{22} \mathrm{~N}_{2} \mathrm{O}_{5} \mathrm{~S}$ & $287.1068,277.1223,190.0901,156.1022$ & Arecoline mercapturic acid & Urine; Plasma \\
\hline M8 & 5.58 & {$[\mathrm{M}+\mathrm{H}]^{+}$} & 343.1862 & -0.417 & $\mathrm{C}_{16} \mathrm{H}_{26} \mathrm{~N}_{2} \mathrm{O}_{6}$ & 172.0974 & Arecoline N-oxide dimer & Urine; Plasma \\
\hline M9 & 5.79 & {$[\mathrm{M}+\mathrm{H}]^{+}$} & 172.0966 & -1.103 & $\mathrm{C}_{8} \mathrm{H}_{13} \mathrm{NO}_{3}$ & $154.0866,140.0710,112.0759$ & Arecoline N-oxide & Urine; Plasma \\
\hline M10a & 7.60 & {$[\mathrm{M}-\mathrm{H}]^{-}$} & 465.1025 & -0.586 & $\mathrm{C}_{21} \mathrm{H}_{22} \mathrm{O}_{12}$ & 289.0719 & Glucuronidation of C/EC & Urine \\
\hline M11 & 7.67 & {$[\mathrm{M}+\mathrm{H}]^{+}$} & 144.1019 & -0.175 & $\mathrm{C}_{7} \mathrm{H}_{13} \mathrm{NO}_{2}$ & $126.0916,98.0965,84.0807$ & N-methylnipecotic acid & Urine; Plasma \\
\hline M12a & 7.90 & {$[\mathrm{M}-\mathrm{H}]^{-}$} & 369.0282 & 1.872 & $\mathrm{C}_{15} \mathrm{H}_{14} \mathrm{O}_{9} \mathrm{~S}$ & 289.0723 & Sulfation of C/EC & Urine \\
\hline M10b & 8.12 & {$[\mathrm{M}-\mathrm{H}]^{-}$} & 465.1037 & 1.973 & $\mathrm{C}_{21} \mathrm{H}_{22} \mathrm{O}_{12}$ & 289.0721 & Glucuronidation of $\mathrm{C} / \mathrm{EC}$ & Urine \\
\hline M12b & 8.22 & {$[\mathrm{M}-\mathrm{H}]^{-}$} & 369.0282 & 2.279 & $\mathrm{C}_{15} \mathrm{H}_{14} \mathrm{O}_{9} \mathrm{~S}$ & 289.0723 & Sulfation of $\mathrm{C} / \mathrm{EC}$ & Urine \\
\hline M13 & 8.33 & {$[\mathrm{M}+\mathrm{H}]^{+}$} & 335.1270 & -0.369 & $\mathrm{C}_{13} \mathrm{H}_{22} \mathrm{~N}_{2} \mathrm{O}_{6} \mathrm{~S}$ & $317.1172,303.1019,293.1173,206.0851,172.0973$ & Arecoline N-oxide mercapturic acid & Urine; Plasma \\
\hline M14 & 8.41 & {$[\mathrm{M}+\mathrm{H}]^{+}$} & 170.0812 & -0.057 & $\mathrm{C}_{8} \mathrm{H}_{11} \mathrm{NO}_{3}$ & 152.0711 & Norepinephrine & Urine; Plasma \\
\hline M10c & 8.47 & {$[\mathrm{M}-\mathrm{H}]^{-}$} & 465.1024 & -0.715 & $\mathrm{C}_{21} \mathrm{H}_{22} \mathrm{O}_{12}$ & 289.0716 & Glucuronidation of $\mathrm{C} / \mathrm{EC}$ & Plasma \\
\hline M15 & 8.60 & {$[\mathrm{M}+\mathrm{H}]^{+}$} & 579.1491 & -1.023 & $\mathrm{C}_{30} \mathrm{H}_{26} \mathrm{O}_{12}$ & 453.1199, 427.1041, 409.0938, 291.0875 & Procyanidin B2 & Urine; Plasma \\
\hline M16a & 9.20 & {$[\mathrm{M}-\mathrm{H}]^{-}$} & 383.0435 & 1.020 & $\mathrm{C}_{16} \mathrm{H}_{16} \mathrm{O}_{9} \mathrm{~S}$ & $303.0879,137.0249$ & Sulfation + methylation of C/EC & Urine \\
\hline M17a & 9.31 & {$[\mathrm{M}+\mathrm{H}]^{+}$} & 291.0865 & 0.602 & $\mathrm{C}_{15} \mathrm{H}_{14} \mathrm{O}_{6}$ & $273.0766,165.0550,151.0394,139.0394,123.0444$ & Catechin $(C)$ & Urine; Plasma \\
\hline M10d & 9.53 & {$[\mathrm{M}-\mathrm{H}]^{-}$} & 465.1031 & 0.790 & $\mathrm{C}_{21} \mathrm{H}_{22} \mathrm{O}_{12}$ & 289.0721 & Glucuronidation of C/EC & Plasma \\
\hline M18a & 9.86 & {$[\mathrm{M}-\mathrm{H}]^{-}$} & 479.1187 & 0.579 & $\mathrm{C}_{22} \mathrm{H}_{24} \mathrm{O}_{12}$ & $303.0877,289.0716,175.0249$ & Methylation + glucuronidation of C/EC & Urine \\
\hline M18b & 10.12 & {$[\mathrm{M}-\mathrm{H}]^{-}$} & 479.1179 & -1.132 & $\mathrm{C}_{22} \mathrm{H}_{24} \mathrm{O}_{12}$ & $303.0873,289.0715,175.0247$ & Methylation + glucuronidation of C/EC & Urine \\
\hline M19a & 10.16 & {$[\mathrm{M}+\mathrm{H}]^{+}$} & 305.1020 & 0.083 & $\mathrm{C}_{16} \mathrm{H}_{16} \mathrm{O}_{6}$ & $287.0921,179.0707$ & Methylation of C/EC & Urine; Plasma \\
\hline M19b & 10.50 & {$[\mathrm{M}+\mathrm{H}]^{+}$} & 305.1021 & 0.280 & $\mathrm{C}_{16} \mathrm{H}_{16} \mathrm{O}_{6}$ & $287.0923,179.0708$ & Methylation of C/EC & Urine; Plasma \\
\hline M16b & 10.73 & {$[\mathrm{M}-\mathrm{H}]^{-}$} & 383.0430 & -0.259 & $\mathrm{C}_{16} \mathrm{H}_{16} \mathrm{O}_{9} \mathrm{~S}$ & $303.0876,137.0249$ & Sulfation + methylation of $\mathrm{C} / \mathrm{EC}$ & Urine \\
\hline M16c & 11.73 & {$[\mathrm{M}-\mathrm{H}]^{-}$} & 383.0427 & -1.225 & $\mathrm{C}_{16} \mathrm{H}_{16} \mathrm{O}_{9} \mathrm{~S}$ & $303.0882,137.0250$ & Sulfation + methylation of $\mathrm{C} / \mathrm{EC}$ & Urine \\
\hline M17b & 11.99 & {$[\mathrm{M}+\mathrm{H}]^{+}$} & 291.0864 & 0.293 & $\mathrm{C}_{15} \mathrm{H}_{14} \mathrm{O}_{6}$ & $273.0767,165.0551,151.0394,139.0394,123.0445$ & Epicatechin(EC) & Urine; Plasma \\
\hline M16d & 12.72 & {$[\mathrm{M}-\mathrm{H}]^{-}$} & 383.0429 & -0.729 & $\mathrm{C}_{16} \mathrm{H}_{16} \mathrm{O}_{9} \mathrm{~S}$ & $303.0882,137.0250$ & Sulfation + methylation of $\mathrm{C} / \mathrm{EC}$ & Urine \\
\hline M19c & 12.94 & {$[\mathrm{M}+\mathrm{H}]^{+}$} & 305.1020 & -0.015 & $\mathrm{C}_{16} \mathrm{H}_{16} \mathrm{O}_{6}$ & $287.0923,179.0708$ & Methylation of C/EC & Urine; Plasma \\
\hline M16e & 13.01 & {$[\mathrm{M}-\mathrm{H}]^{-}$} & 383.0436 & 1.334 & $\mathrm{C}_{16} \mathrm{H}_{16} \mathrm{O}_{9} \mathrm{~S}$ & $303.0876,137.0250$ & Sulfation + methylation of $\mathrm{C} / \mathrm{EC}$ & Plasma \\
\hline M20 & 13.06 & {$[\mathrm{M}+\mathrm{H}]^{+}$} & 184.0968 & -0.271 & $\mathrm{C}_{9} \mathrm{H}_{13} \mathrm{NO}_{3}$ & $166.0865,152.0710$ & Epinephrine(EP) & Urine \\
\hline M16f & 13.29 & {$[\mathrm{M}-\mathrm{H}]^{-}$} & 383.0432 & 0.289 & $\mathrm{C}_{16} \mathrm{H}_{16} \mathrm{O}_{9} \mathrm{~S}$ & $303.0875,137.0249$ & Sulfation + methylation of C/EC & Plasma \\
\hline M18c & 13.70 & {$[\mathrm{M}-\mathrm{H}]^{-}$} & 479.1183 & -0.297 & $\mathrm{C}_{22} \mathrm{H}_{24} \mathrm{O}_{12}$ & $303.0876,289.0718,175.0249$ & Methylation + glucuronidation of C/EC & Plasma \\
\hline M12c & 13.89 & {$[\mathrm{M}-\mathrm{H}]^{-}$} & 369.0271 & -0.946 & $\mathrm{C}_{15} \mathrm{H}_{14} \mathrm{O}_{9} \mathrm{~S}$ & 289.0722 & Sulfation of $\mathrm{C} / \mathrm{EC}$ & Plasma \\
\hline M18d & 13.93 & {$[\mathrm{M}-\mathrm{H}]^{-}$} & 479.1179 & -1.007 & $\mathrm{C}_{22} \mathrm{H}_{24} \mathrm{O}_{12}$ & $303.0876,289.0717,175.0249$ & Methylation + glucuronidation of C/EC & Plasma \\
\hline M21 & 14.27 & {$[\mathrm{M}+\mathrm{H}]^{+}$} & 321.0943 & -2.549 & $\mathrm{C}_{16} \mathrm{H}_{16} \mathrm{O}_{7}$ & $303.1331,289.0689$ & Methylation of epigallocatechin(EGC) & Urine \\
\hline M16g & 14.34 & {$[\mathrm{M}-\mathrm{H}]^{-}$} & 383.0432 & 2.378 & $\mathrm{C}_{16} \mathrm{H}_{16} \mathrm{O}_{9} \mathrm{~S}$ & $303.0883,137.0250$ & Sulfation + methylation of C/EC & Plasma \\
\hline M19d & 14.35 & {$[\mathrm{M}+\mathrm{H}]^{+}$} & 305.1018 & -0.507 & $\mathrm{C}_{16} \mathrm{H}_{16} \mathrm{O}_{6}$ & $287.0920,179.0706$ & Methylation of C/EC & Urine \\
\hline M12d & 14.68 & {$[\mathrm{M}-\mathrm{H}]^{-}$} & 369.0270 & -1.352 & $\mathrm{C}_{15} \mathrm{H}_{14} \mathrm{O}_{9} \mathrm{~S}$ & 289.0722 & Sulfation of C/EC & Plasma \\
\hline
\end{tabular}




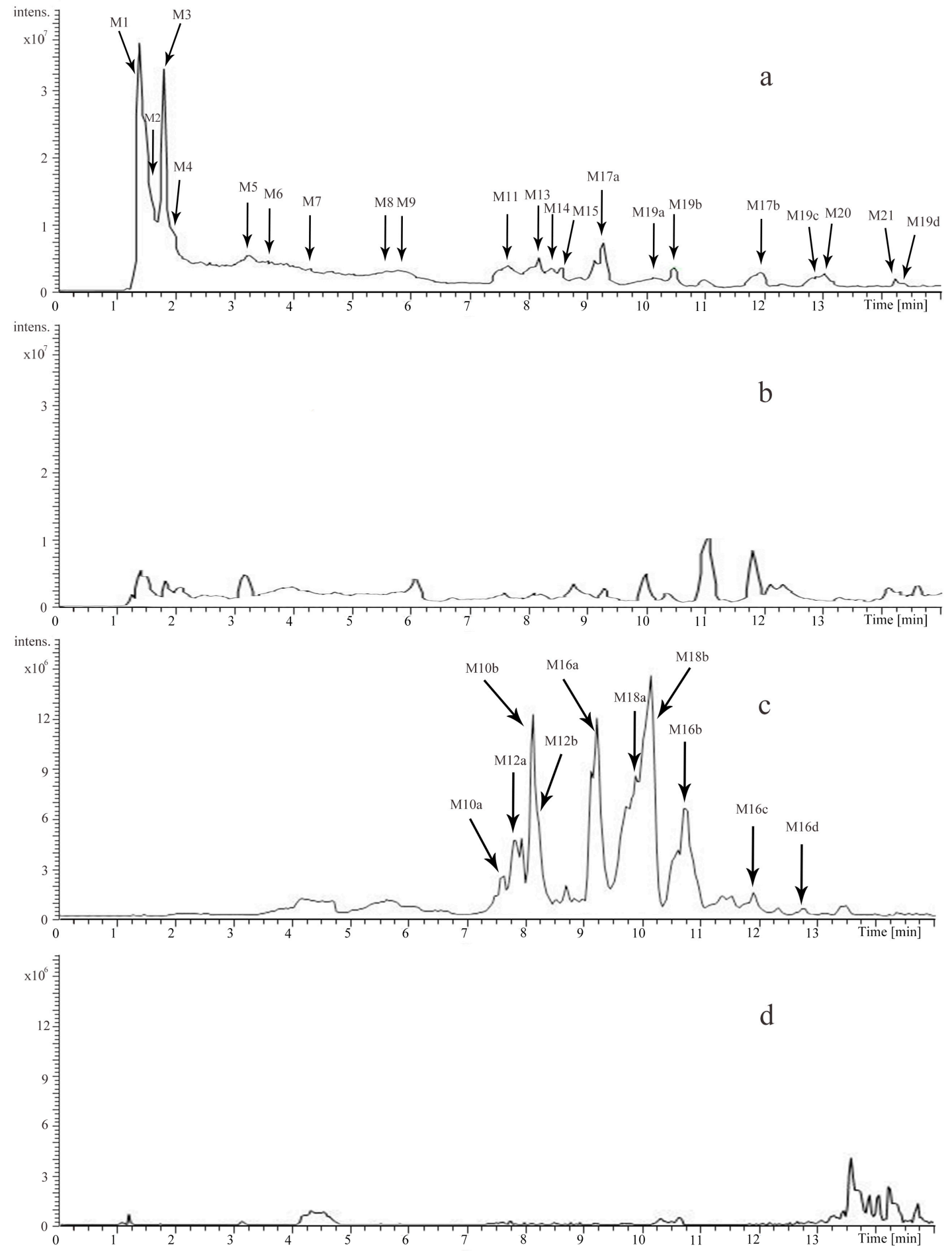

Figure 4. Extracted ion chromatograms of the urine sample in positive ion mode (a); the blank urine sample in positive ion mode (b); the urine sample in negative ion mode (c); the blank urine sample in negative ion mode $(\mathbf{d})$. 

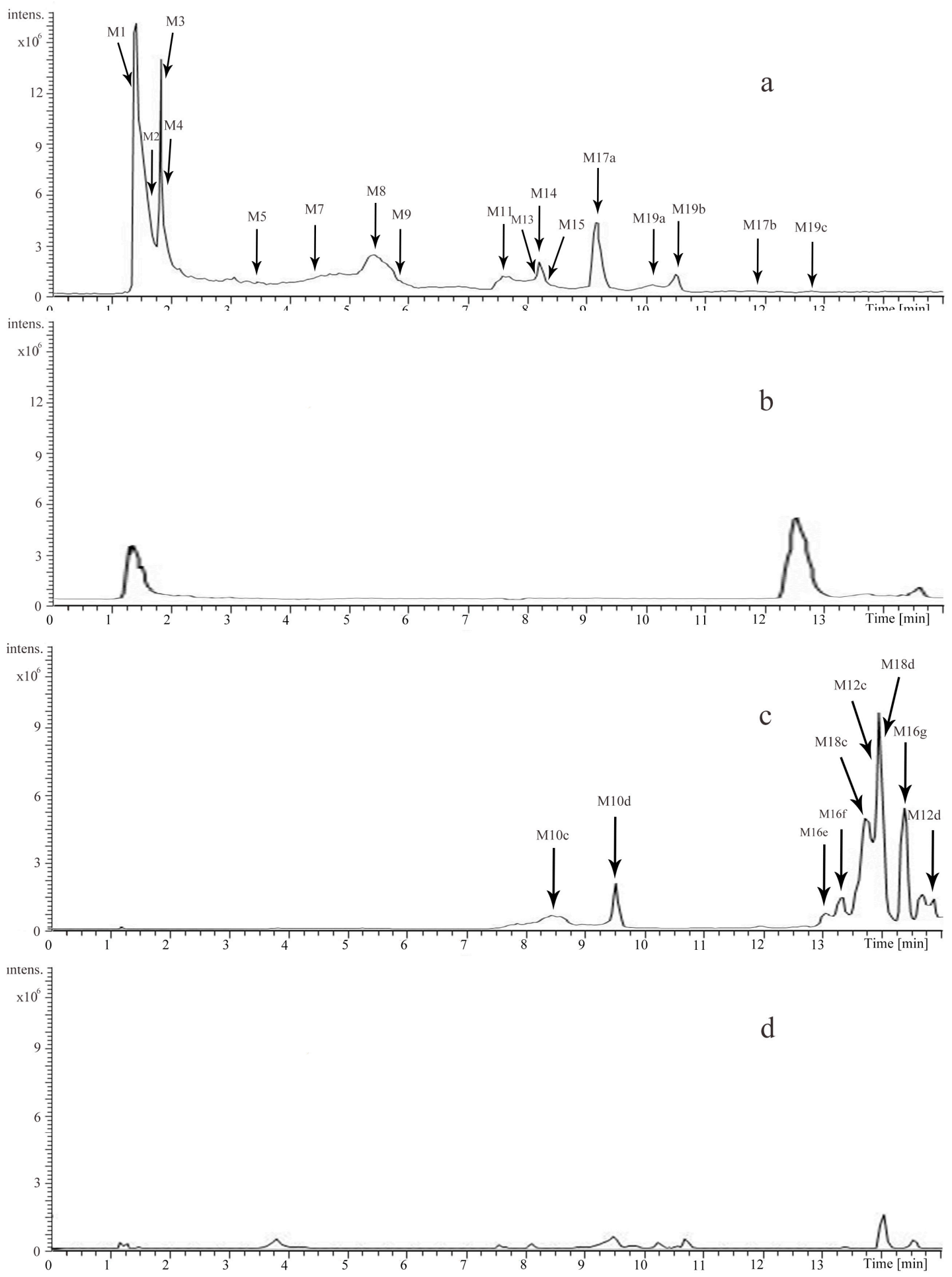

Figure 5. Extracted ion chromatograms of the plasma sample in positive ion mode (a); the blank plasma sample in positive ion mode (b); the plasma sample in negative ion mode (c); the blank plasma sample in negative ion mode $(\mathbf{d})$. 


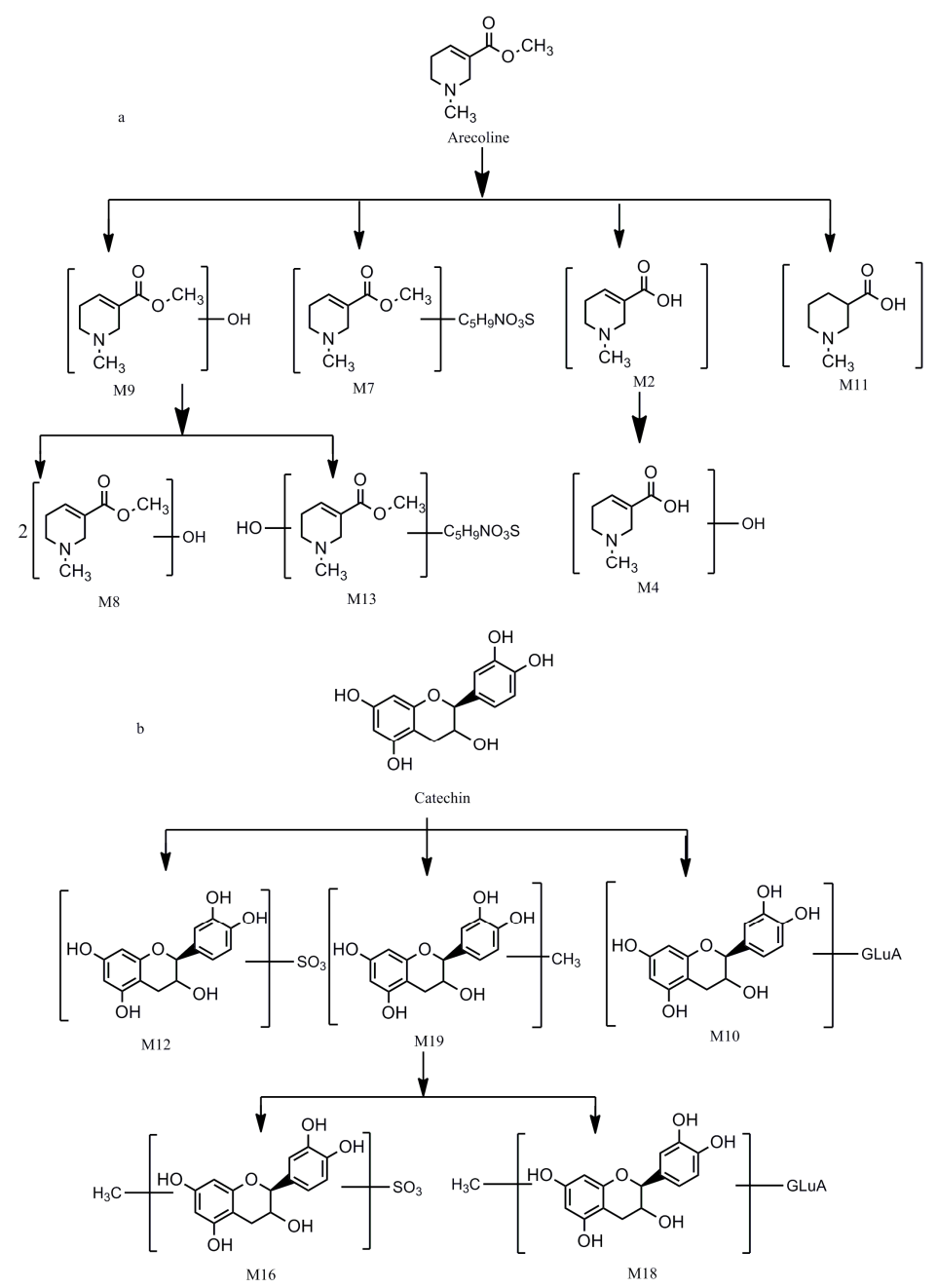

Figure 6. The proposed metabolic pathways of arecoline (a) and catechin (b).

\subsubsection{Prototypes (M1, M2, M3, M5, M6, M15, M17)}

M1 (1.75 $\mathrm{min},-0.352 \mathrm{ppm})$ showed the $[\mathrm{M}+\mathrm{H}]^{+}$ion at $m / z 128.0706$, and gave rise to two product ions at $m / z 110.0601$ and 81.0332, which were consistent with the product ions of component 2. Therefore, M1 was identified as guvacine or isoguvacine.

M2 (1.76 $\mathrm{min},-0.740 \mathrm{ppm})$ displayed the $[\mathrm{M}+\mathrm{H}]^{+}$ion at $m / z 142.0862$, and produced fragment ions at $m / z 124.0759,96.0809$ and 81.0334 corresponding to component 3 . Thus, M2 was tentatively identified as arecaidine.

M3 (1.78 $\mathrm{min},-0.661 \mathrm{ppm})$ showed the $[\mathrm{M}+\mathrm{H}]^{+}$ion at $m / z 144.1018$, and it produced the fragment ions at $m / z 126.0915,114.0915$ and 84.0806 corresponding to component 4 . Based on these data, M3 was identified as methyl piperidine-3-carboxylate.

M5 (3.28 $\mathrm{min},-0.388 \mathrm{ppm}$ ) displayed the same $[\mathrm{M}+\mathrm{H}]^{+}$ion at $m / z$ 142.0862. In the MS/MS spectrum, M5 led three major fragment ions at $m / z$ 113.0597, 110.0601 and 81.0333 which were consistent with component 6 . Therefore, M5 was tentatively identified as guvacoline.

M6 (3.58 min, $-0.418 \mathrm{ppm}$ ) displayed the $[\mathrm{M}+\mathrm{H}]^{+}$ion at $m / z$ 156.1018. In the MS/MS spectrum, M6 yielded ions at $m / z$ 124.0758, 113.0598, 96.0807 and 81.0333, which were the diagnostic ions of component 7. Thus, M6 was confirmed as arecoline.

M15 (8.60 $\mathrm{min},-1.023 \mathrm{ppm}$ ) exhibited the $[\mathrm{M}+\mathrm{H}]^{+}$ion at $m / z 579.1491$, and led to four major product ions at $m / z 453.1199,427.1041,409.0938$ and 291.0875, which were the characteristic fragment ions of component 9 . Consequently, M15 was tentatively considered to be procyanidin B2. 
M17a (9.31 min, $0.602 \mathrm{ppm}$ ) and M17b (11.99 min, $0.293 \mathrm{ppm}$ ) gave the same molecular ion at $\mathrm{m} / \mathrm{z}$ 291, and in the MS/MS spectrum both of them displayed the fragment ions at $m / z 273.0766,165.0550$, 151.0394, 139.0394 and 123.0444, corresponding to components 10 and 12. Thus, M17a and M17b were confirmed as catechin (C) and epicatechin (EC), respectively.

\subsubsection{Methylated Metabolites (M19, M21)}

M19a (10.16 min, $0.083 \mathrm{ppm})$, M19b (10.50 min, $0.280 \mathrm{ppm})$, M19c (12.94 min, $-0.015 \mathrm{ppm}$ ) and M19d (14.35 min, $-0.507 \mathrm{ppm}$ ) showed the same $[\mathrm{M}+\mathrm{H}]^{+}$ion at $m / z 305$, which was an increase of $14 \mathrm{Da}\left(\mathrm{CH}_{2}\right)$ when compared with that of M17 (C/EC). Further MS ${ }^{2}$ spectra of them showed product ions at $m / z 287.0921\left[\mathrm{M}+\mathrm{H}-\mathrm{H}_{2} \mathrm{O}\right]^{+}$and $179.0707\left[\mathrm{M}+\mathrm{H}_{-} \mathrm{C}_{6} \mathrm{H}_{6} \mathrm{O}_{3}\right]^{+}$, indicating the methylation was asserted on the $\mathrm{B}$ ring. Based on these data, M19a-d were tentatively assessed as methylated C/EC.

M21 (14.27 min, $-2.549 \mathrm{ppm})$ gave the $[\mathrm{M}+\mathrm{H}]^{+}$ion at $m / z 321.0943$, which was also an increase of $14 \mathrm{Da}\left(\mathrm{CH}_{2}\right)$ when compared with that of epigallocatechin (EGC). In the MS/MS spectrum, M21 exhibited the fragment ions at $m / z 303.1331\left[\mathrm{M}+\mathrm{H}-\mathrm{H}_{2} \mathrm{O}\right]^{+}$and $289.0689\left[\mathrm{M}+\mathrm{H}-\mathrm{H}_{2} \mathrm{O}-\mathrm{CH}_{3}\right]^{+}$. In accordance with [29], M21 was identified as methylated EGC.

\subsubsection{Methylated and Sulfated Metabolites (M16)}

M16a (9.20 min, 1.020 ppm), M16b (10.73 min, -0.259 ppm), M16c (11.73 min, -1.225 ppm), M16d (12.72 min, -0.729 ppm), M16e (13.01 min, $1.334 \mathrm{ppm})$, M16f (13.29 min, $0.289 \mathrm{ppm}$ ) and M16g (14.34 min, $2.378 \mathrm{ppm}$ ) displayed the same $[\mathrm{M}-\mathrm{H}]^{-}$ion at $m / z 383$, which was $80 \mathrm{Da}\left(\mathrm{SO}_{3}\right)$ higher than that of M19, suggesting M16a-g were the sulfate conjugations of M19. Furthermore, the fragment ion of M16 at $m / z 137.0249\left[\mathrm{M}-\mathrm{H}-\mathrm{SO}_{3}-\mathrm{C}_{8} \mathrm{H}_{7} \mathrm{O}_{3}\right]^{-}$indicated that the sulfation occurred on the A ring.

\subsubsection{Methylated and Glucuronidated Metabolites (M18)}

M18a (9.86 min, 0.579 ppm), M18b (10.12 min, -1.132 ppm), M18c (13.70 min, -0.297 ppm) and M18d (13.93 min, $-1.007 \mathrm{ppm}$ ) both showed $[\mathrm{M}-\mathrm{H}]^{-}$ion at $m / z 479$, which was 176 Da heavier than that of M19, indicating M18 was the glucuronide conjugation of M19. In the MS/MS spectrum, M18 produced three major fragment ions at $m / z 303.0877,289.0716$ and 175.0249. The ion at $m / z 303.0877$ was generated through a neutral loss of $176 \mathrm{Da}(\mathrm{GluA})$, the ion at $m / z 175.0249$ was the $[\mathrm{M}-\mathrm{H}]^{-}$ion of GluA, and the ion at $m / z 289.0716$ was the characteristic ion of C/EC.

\subsubsection{Sulfated Metabolites (M12)}

M12a (7.90 min, $1.872 \mathrm{ppm})$, M12b (8.22 $\mathrm{min}, 2.279 \mathrm{ppm})$, M12c (13.89 $\mathrm{min},-0.946 \mathrm{ppm}$ ) and M12d (14.68 min, $-1.352 \mathrm{ppm}$ ) exhibited $[\mathrm{M}-\mathrm{H}]^{-}$ion at $m / z 369$, which were 80 Da heavier than that of the M17, suggesting M12 were the sulfate conjugations of C/EC. The major fragment ion at $m / z 289.0723$ was the characteristic ion of C/EC.

\subsubsection{Glucuronidated Metabolites (M10)}

M10a (7.60 min, $-0.586 \mathrm{ppm})$, M10b (8.12 $\mathrm{min}, 1.973 \mathrm{ppm})$, M10c (8.47 $\mathrm{min},-0.715 \mathrm{ppm})$ and M10d (9.53 min, $0.790 \mathrm{ppm}$ ) gave the $[\mathrm{M}-\mathrm{H}]^{-}$ion at $\mathrm{m} / \mathrm{z} 465$, which was an increase of $176 \mathrm{Da}$ (GluA) when compared with that of M17. In the MS/MS spectrum, M10 gave rise to the characteristic ion of C/EC at $m / z$ 289.0719. Based on these data, M10 should be the glucuronidated product of C/EC.

\subsubsection{Oxidative Metabolites (M4, M9)}

M4 (1.96 min, $-0.315 \mathrm{ppm})$ displayed $[\mathrm{M}+\mathrm{H}]^{+}$ion at $m / z$ 158.0811, which was $16 \mathrm{Da}(\mathrm{O})$ heavier than that of M2. In the MS/MS spectrum, M4 gave rise to two main fragment ions at $m / z 140.0529$ $\left[\mathrm{M}+\mathrm{H}-\mathrm{OH}-\mathrm{H}_{2}\right]^{+}$and $m / z 112.0870\left[\mathrm{M}+\mathrm{H}-\mathrm{COOH}-\mathrm{H}_{2}\right]^{+}$. Therefore, $\mathrm{M} 4$ might be the oxide of $\mathrm{M} 2$.

M9 (5.79 min, $-1.103 \mathrm{ppm}$ ) exhibited $[\mathrm{M}+\mathrm{H}]^{+}$ion at $m / z$ 172.0966, which was $16 \mathrm{Da}(\mathrm{O})$ higher than that of M6. In the MS/MS spectrum, M9 produced the fragment ions at $m / z 154.0866$ 
$\left[\mathrm{M}+\mathrm{H}-\mathrm{OH}-\mathrm{H}_{2}\right]^{+}, 140.0710\left[\mathrm{M}+\mathrm{H}-\mathrm{OCH}_{3}-\mathrm{H}_{2}\right]^{+}$and $112.0759\left[\mathrm{M}+\mathrm{H}-\mathrm{C}_{2} \mathrm{H}_{4} \mathrm{O}_{2}\right]^{+}$. Thus, M9 was tentatively identified as the oxide of M6.

\subsubsection{Mercapturic Acid-Conjugated Metabolites (M7)}

M7 (4.31 min, $-1.000 \mathrm{ppm}$ ) exhibited the $[\mathrm{M}+\mathrm{H}]^{+}$ion at $m / z$ 319.1319. In the MS/MS spectrum, M7 produced four major fragment ions at $m / z 287.1068\left[\mathrm{M}+\mathrm{H}_{-} \mathrm{CH}_{2}-\mathrm{H}_{2} \mathrm{O}\right]^{+}, 277.1223\left[\mathrm{M}+\mathrm{H}-\mathrm{COCH}_{3}\right]^{+}$, $190.0901\left[\mathrm{M}+\mathrm{H}-\mathrm{C}_{5} \mathrm{H}_{7} \mathrm{NO}_{3}\right]^{+}$and $156.1022\left[\mathrm{M}+\mathrm{H}-\mathrm{C}_{5} \mathrm{H}_{9} \mathrm{NO}_{3} \mathrm{~S}\right]^{+}$. The ion at $\mathrm{m} / z 156.1022$ was the characteristic ion of arecoline. In accordance with [30], M8 was tentatively identified as arecoline mercapturic acid.

\subsubsection{Oxidative and Mercapturic Acid Conjugated Metabolites (M13)}

M13 (8.33 min, $-0.369 \mathrm{ppm}$ ) displayed the $[\mathrm{M}+\mathrm{H}]^{+}$ion at $m / z 335.1270$, which was $16 \mathrm{Da}(\mathrm{O})$ heavier than M7. In the MS/MS spectrum, M13 gave rise to five major fragment ions at $\mathrm{m} / \mathrm{z} 317.1172$ $\left[\mathrm{M}+\mathrm{H}-\mathrm{H}_{2} \mathrm{O}\right]^{+}, 303.1019\left[\mathrm{M}+\mathrm{H}-\mathrm{H}_{2} \mathrm{O}-\mathrm{CH}_{2}\right]^{+}, 293.1173\left[\mathrm{M}+\mathrm{H}-\mathrm{COCH}_{3}\right]^{+}, 206.0851\left[\mathrm{M}+\mathrm{H}_{-} \mathrm{C}_{5} \mathrm{H}_{7} \mathrm{NO}_{3}\right]^{+}$ and $172.0973\left[\mathrm{M}+\mathrm{H}-\mathrm{C}_{5} \mathrm{H}_{9} \mathrm{NO}_{3} \mathrm{~S}\right]^{+}$. Among the product ions, the ion at $m / z 172.0973$ was the typical ion of arecoline $\mathrm{N}$-oxide (M10). Therefore, M13 was tentatively identified as arecoline $\mathrm{N}$-oxide mercapturic acid.

\subsubsection{Dimer (M8)}

M8 (5.58 $\mathrm{min},-0.417 \mathrm{ppm}$ ) showed the molecular ion at $m / z 343.1862$, which was an increase of 171 Da compared to M9, suggesting M8 was the two dimer of M9. In the MS/MS spectrum, M8 produced the main fragment ion at $m / z$ 172.0974, which was the characteristic ion of M9.

\subsubsection{Other Metabolites (M11, M14, M20)}

M11 (7.67 min, $-0.175 \mathrm{ppm})$ exhibited the $[\mathrm{M}+\mathrm{H}]^{+}$ion at $m / z 144.1019$, which was 2 Da heavier than that of arecaidine, indicating it was hydrogenated product of arecaidine. In the MS/MS spectrum, it produced three major fragment ions at $m / z 126.0916[\mathrm{M}+\mathrm{H}-\mathrm{OH}]^{+}, 98.0965[\mathrm{M}+\mathrm{H}-\mathrm{COOH}]^{+}$and $84.0807\left[\mathrm{M}+\mathrm{H}-\mathrm{CH}_{3}-\mathrm{COOH}\right]^{+}$. Accordingly [30], M11 was proposed to be $\mathrm{N}$-methylnipecotic acid.

M20 (13.06 $\mathrm{min},-0.271 \mathrm{ppm})$ displayed the $[\mathrm{M}+\mathrm{H}]^{+}$ion at $\mathrm{m} / z 184.0968$, and in the MS/MS spectrum it yielded the major fragment ions at $m / z 166.0865\left[\mathrm{M}+\mathrm{H}_{-}-\mathrm{H}_{2} \mathrm{O}\right]^{+}$and 152.0710 $\left[\mathrm{M}+\mathrm{H}-\mathrm{H}_{2} \mathrm{O}-\mathrm{CH}_{3}\right]^{+}$. It was tentatively identified as epinephrine (EP).

M14 (8.41 min, $-0.057 \mathrm{ppm}$ ) showed the $[\mathrm{M}+\mathrm{H}]^{+}$ion at $m / z 170.0812$, which was a loss of $14 \mathrm{Da}$ $\left(\mathrm{CH}_{2}\right)$ compared with M20. In the MS/MS spectrum, M14 gave rise to the major fragment ion at $m / z$ $152.0711\left[\mathrm{M}+\mathrm{H}-\mathrm{H}_{2} \mathrm{O}\right]^{+}$. Thus, M14 was tentatively identified as confirmed as norepinephrine.

\section{Materials and Methods}

\subsection{Chemicals and Materials}

Areca catechu L. nut was obtained from Tongrentang Pharmaceutical Co., Ltd. (Beijing, China), and authenticated by Professor Jingjuan Wang (Beijing University of Chinese Medicine). HPLC-grade acetonitrile, methanol and formic acid were purchased from Fisher Scientific. High pure water was obtained from Watson's Food \& Beverage (Guangzhou, China). All other reagents were of analytical grade and commercially available.

\subsection{Preparation of the Areca catechu L. Nut Extract}

Areca catechu L. nut was ground into a crude powder. At room temperature, $100 \mathrm{~g}$ powdered nut was soaked in $1 \mathrm{~L}$ water for $1 \mathrm{~h}$. After filtering, the residue was added to $0.8 \mathrm{~L}$ water for further extraction under the same conditions. The two filtrates were combined and evaporated to the final volume of $20 \mathrm{~mL}$ in a vacuum at $45^{\circ} \mathrm{C}$ to obtain an oral solution $(5 \mathrm{~g} / \mathrm{mL})$. For LC/MS analysis, the 
Areca catechu L. nut extract $(5 \mathrm{~g} / \mathrm{mL})$ was diluted to a concentration of $10 \mathrm{mg} / \mathrm{mL}$ with water, and then the solution was filtered through a $0.22 \mu \mathrm{m}$ membrane (pore size).

\subsection{Animal and Sample Collection}

Sprague-Dawley rats (male, 200-250 g) were provided by Beijing Vital River Laboratory Animal Technology Co., Ltd. (Beijing, China). All animals were kept in an environmentally controlled breeding room at $23{ }^{\circ} \mathrm{C}, 60 \pm 5 \%$ humidity with room-lights alternated on a 12-h dark-light cycle. Water and standard diet were provided ad libitum. The animal facilities and protocols were approved by the Institutional Animal Care and Use Committee of Beijing University of Chinese Medicine.

Rats were randomly separated into two groups of three animals each and were acclimated in metabolic cages for three days. Prior to the experiment, the rats were fasted overnight with unlimited access to water. Then, the treatment group rats were given ACNE intragastrically at a single dose of $50 \mathrm{~g} / \mathrm{kg}$ (crude drug weight/rat weight). Blank control group rats were orally administered with equal dose of saline at the same time. The animals were continuously administered twice per day. Then, $1.5 \mathrm{~h}$ after the seventh drug administration, the animals were anesthetized with chloral hydrate $(400 \mathrm{mg} / \mathrm{kg}$ ) by intraperitoneal injection. Then, blood samples were collected from the abdominal aorta. Urine samples were collected every $12 \mathrm{~h}$ after the first drug administration, then, all urine samples from each animal were combined into one sample. After the experiments, all rats were sacrificed by performing a bilateral thoracotomy.

\subsection{Sample Preparation}

Each blood sample was centrifuged $\left(5000 \mathrm{rpm}, 4^{\circ} \mathrm{C}\right.$ ) for $10 \mathrm{~min}$ to obtain the plasma, and then treated by addition of methanol in the ratio of $1: 3(v / v)$ to precipitate protein. The mixture was performed by vortexing for $10 \mathrm{~min}$ and centrifuging $\left(10,000 \mathrm{rpm}, 4^{\circ} \mathrm{C}\right)$ for $15 \mathrm{~min}$. The supernatant was transferred to another clean tube, and dried under a gentle flow of nitrogen at $40{ }^{\circ} \mathrm{C}$. Then the dried residue was reconstituted with $200 \mu \mathrm{L}$ of methanol for UHPLC-LTQ-Orbitrap analysis.

Each urine sample $(10 \mathrm{~mL})$ was concentrated to the final volume of $5 \mathrm{~mL}$ in a vacuum. Then, 500 microL urine were mixed with $1.5 \mathrm{~mL}$ of methanol and sonicated in an ultrasonic bath for $0.5 \mathrm{~h}$, and then centrifuged $\left(10,000 \mathrm{rpm}, 4^{\circ} \mathrm{C}\right)$ for $10 \mathrm{~min}$. The supernatant was transferred to another clean tube, and dried under a gentle flow of nitrogen at $40{ }^{\circ} \mathrm{C}$. The dried residue was reconstituted with $200 \mu \mathrm{L}$ of methanol for UHPLC-LTQ-Orbitrap analysis.

\subsection{Instrumentation and Analytical Conditions}

Sample analyses were performed using an ultimate 3000 LC system coupled to an LTQ Orbitrapmass spectrometer via an electrospray ionization (ESI) interface. The chromatography system consisted of an autosampler, a diode array detector, a column compartment and two pumps. Xcalibur, Metworks and Mass Frontier 7.0 software packages (Thermo Corporation, Waltham, MA, USA) were employed for data collection and data analysis.

Chromatographic separations were performed on a Thermo Scientific BOS Hypersil $C_{18}$ column $2.1 \times 150 \mathrm{~mm}^{2}$, with $2.4-\mu \mathrm{m}$ particle size. The mobile phases A and B comprised $0.1 \%$ formic acid in water and acetonitrile, respectively. The LC gradient program (time (in min) \%mobile phase B) was set at $0.01 / 2,5 / 2,5.1 / 10,10 / 10,25 / 80,26 / 2$, and $31 / 2$. The chromatographic runs were performed at a flow rate of $0.3 \mathrm{~mL} / \mathrm{min}$. The injection volume was $3 \mu \mathrm{L}$ with column oven at $35^{\circ} \mathrm{C}$.

The ESI source parameters were as follows: the capillary temperature was $250^{\circ} \mathrm{C}$, source voltage and the spray voltage were set at $5 \mathrm{kV}$, and sheath gas $\left(\mathrm{N}_{2}\right)$ flow was $35 \mathrm{psi}$. The ESI source was operated in both negative and positive ionization mode. In the Fourier transform (FT) cell, full MS scans were acquired in the range of $m / z 50-2000$. The MS/MS experiments were set as data-dependent scans. 


\section{Conclusions}

In this study, a sensitive LC/MS method was established for the comprehensive analysis and profiling of the multiple components of $\mathrm{ACNE}$ and their absorption and metabolite components in rats after oral administration. In total, 12 components were detected and identified on the basis of the retention times on the UHPLC system, the accurate molecular mass, and characteristic product ions. After oral administration of ACNE to rats, a total of 40 exogenous chemical compounds were identified in urine and plasma, including 8 prototypes and 32 metabolites. The major metabolic reactions of ACNE were proposed, including methylation, sulfation, glucuronidation, oxidation, and mercapturic acid conjugation. All above mentioned results laid a solid foundation for further pharmacological and toxicological research of Areca catechu L. nut, which will facilitate its clinical usage and drug discovery.

Supplementary Materials: Supplementary materials are available online. Figure S1: Extracted ion chromatogram of each major component identified in ACNE.

Acknowledgments: This work is supported by Special Research Grant for Non-profit Public Service (No. 201507004 and BUCMHZ-2015026).

Author Contributions: Authors Lulu Li and Zhiqiang Luo contributed equally to this article. Yang Liu and Baosheng Zhao conceived and designed the experiments; Zhiqiang Luo, Hao Wang, Aoxue Liu, and Mengwei Li performed the experiments; Lulu Li, Guohua Yu, and Ruirui Yang analyzed the data; Xinjing Chen and Jialian Zhu contributed reagents/materials/analysis tools; Lulu Li and Zhiqiang Luo wrote the paper. All the authors gave the final approval of the version to be submitted.

Conflicts of Interest: The authors declare no conflict of interest.

\section{References}

1. Wang, P.; Lv, H.T.; Zhang, A.H.; Sun, H.; Yan, G.L.; Han, Y.; Wu, X.H.; Wang, X.J. Improved ultra-performance liquid chromatography with electrospray ionization quadrupole-time-of-flight high-definition mass spectrometry method for the rapid analysis of the chemical constituents of a typical medical formula: Liuwei Dihuang Wan. J. Sep. Sci. 2013, 36, 3511-3516. [CrossRef] [PubMed]

2. Zhan, C.S.; Xiong, A.Z.; Shen, D.P.; Li, Y.; Wang, Z.T. Characterization of the Principal Constituents of Danning Tablets, a Chinese Formula Consisting of Seven Herbs, by an UPLC-DAD-MS/MS Approach. Molecules 2016, 21, 631. [CrossRef] [PubMed]

3. Yan, X.M.; Zhang, Q.Y.; Feng, F. Chemical profiling approach to evaluate the influence of traditional and simplified decoction methods on the holistic quality of Da-Huang-Xiao-Shi decoction using high-performance liquid chromatography coupled with diode-array detection and time-of-flight mass spectrometry. J. Sep. Sci. 2016, 39, 1442-1453. [PubMed]

4. Yan, G.L.; Zou, D.; Zhang, A.H.; Tan, Y.L.; Sun, H.; Wang, X.J. UPLC-Q-TOF-MS/MS fingerprinting for rapid identification of chemical constituents of Ermiao Wan. Anal. Methods 2014, 7, 846-862. [CrossRef]

5. Luo, K.W.; Shi, Q.S.; Feng, F. Characterization of global metabolic profile of Zhi-Zi-Hou-Po decoction in rat bile, urine and feces after oral administration based on a strategy combining LC-MS and chemometrics. J. Chromatogr. B 2016, 1040, 260-272. [CrossRef] [PubMed]

6. Liang, J.; Xu, F.; Zhang, Y.Z.; Huang, S.; Zang, X.Y.; Zhao, X.; Zhang, L.; Shang, M.Y.; Yang, D.H.; Wang, X. The profiling and identification of the absorbed constituents and metabolites of Paeoniae Radix Rubra decoction in rat plasma and urine by the HPLC-DAD-ESI-IT-TOF-MS ${ }^{(\mathrm{n})}$ technique: A novel strategy for the systematic screening and identification of absorbed. J. Pharm. Biomed. Anal. 2013, 83, 108-121. [CrossRef] [PubMed]

7. Jin, Y.; Wu, C.S.; Zhang, J.L.; Li, Y.F. A new strategy for the discovery of epimedium metabolites using high-performance liquid chromatography with high resolution mass spectrometry. Anal. Chim. Acta 2013, 768, 111-117. [CrossRef] [PubMed]

8. Deng, Y.C.; Liu, R.; Yang, P.; Liang, J.Y. Rapid identification of efavirenz metabolites in rats and humans by ultra high performance liquid chromatography combined with quadrupole time-of-flight tandem mass spectrometry. J. Sep. Sci. 2015, 38, 1529-1536. [CrossRef] [PubMed] 
9. Hu, L.; Lv, Z.H.; Li, G.; Xu, X.L.; Zhang, C.H.; Cao, P.; Huang, J.G.; Si, L.Q. Study of the in vitro metabolism of TJ0711 using ultra high performance liquid chromatography with quadrupole time-of-flight and ultra fast liquid chromatography with quadrupole linear ion trap mass spectrometry. J. Sep. Sci. 2015, 38, 1837-1849. [CrossRef] [PubMed]

10. Han, H.; Zeng, W.L.; He, C.Y.; Bligh, S.; Liu, Q.; Yang, L.; Wang, Z.T. Characterization of metabolites of sweroside in rat urine using ultra-high-performance liquid chromatography combined with electrospray ionization quadrupole time-of-flight tandem mass spectrometry and NMR spectroscopy. J. Mass Spectrom. 2014, 49, 1108-1116. [CrossRef] [PubMed]

11. Huang, X.H.; Guo, C.N.; Chen, Z.L.; Liu, Y.H.; He, L.M.; Zeng, Z.L.; Yan, C.Q.; Pan, G.F.; Li, S.P. Metabolism of nitazoxanide in rats, pigs, and chickens: Application of liquid chromatography coupled to hybrid linear ion trap/Orbitrap mass spectrometer. J. Chromatogr. B 2015, 1000, 147-154. [CrossRef] [PubMed]

12. Luo, Z.Q.; Ma, X.Y.; Liu, Y.; Lu, L.N.; Yang, R.R.; Yu, G.H.; Sun, M.H.; Xin, S.K.; Tian, S.M.; Chen, X.J. An Approach to Characterizing the Complicated Sequential Metabolism of Salidroside in Rats. Molecules 2016, 21, 706. [CrossRef] [PubMed]

13. Peng, W.; Liu, Y.J.; Wu, N.; Sun, T.; He, X.Y.; Gao, Y.X.; Wu, C.J. Areca catechu L. (Arecaceae): A review of its traditional uses, botany, phytochemistry, pharmacology and toxicology. J. Ethnopharmacol. 2015, 164, 340-356. [CrossRef] [PubMed]

14. Azeez, S.; Amudhan, S.; Adiga, S.; Rao, N.; Udupa, L.A. Wound healing profile of Areca catechu extracts on different wound models in wistar rats. Kuwait Med. J. 2007, 39, 48-52.

15. Bhandare, A.M.; Vyawahare, N.S.; Kshirsagar, A.D. Anti-migraine effect of Areca Catechu L. nut extract in bradykinin-induced plasma protein extravasation and vocalization in rats. J. Ethnopharmacol. 2015, 171, 121-124. [CrossRef] [PubMed]

16. Dar, A.; Khatoon, S.; Rahman, G.; Atta, U.R. Anti-depressant activities of Areca catechu fruit extract. Phytomed. Int. J. Phytother. Phytopharmacol. 1997, 4, 41-45. [CrossRef]

17. Mukherjee, P.K.; Maiti, K.; Mukherjee, K.; Houghton, P.J. Leads from Indian medicinal plants with hypoglycemic potentials. J. Ethnopharmacol. 2006, 106, 1-28. [CrossRef] [PubMed]

18. Hamsar, M.N.; Ismail, S.; Mordi, M.N.; Ramanathan, S.; Mansor, S.M. Antioxidant activity and the effect of different parts of Areca catechu extracts on Glutathione-S-Transferase activity in vitro. Free Radic. Antioxid. 2011, 1, 28-33. [CrossRef]

19. Wu, P.F.; Chiang, T.A.; Chen, M.T.; Lee, C.P.; Chen, P.H.; Ko, A.M.; Yang, K.J.; Chang, P.Y.; Ke, D.S.; Ko, Y.C. A characterization of the antioxidant enzyme activity and reproductive toxicity in male rats following sub-chronic exposure to areca nut extracts. J. Hazard. Mater. 2010, 178, 541-546. [CrossRef] [PubMed]

20. Hu, Y.X.; Zang, X.B.; Qiu, F.; Nie, Y.; Hu, Y.M.; Hu, S.M.; Pan, C.H.; Zhou, Y.C. The effect of Areca nut on the sperms of mice. Teratog. Carcinog. Mutagen. 1999, 11, 39-41.

21. Sun, M.H.; Luo, Z.Q.; Liu, Y.; Yang, R.R.; Lu, L.N.; Yu, G.H.; Ma, X.Y.; Liu, A.X.; Guo, Y.F.; Zhao, H.Y. Identification of the Major Components of Buddleja officinalis Extract and Their Metabolites in Rat Urine by UHPLC-LTQ-Orbitrap. J. Food Sci. 2016, 81, H2587-H2596. [CrossRef] [PubMed]

22. Zuo, A.H.; Wang, L.; Xiao, H.B.; Li, L.M.; Liu, Y.H.; Yi, J.H. Identification of the absorbed components and metabolites in rat plasma after oral administration of Rhizoma Chuanxiong decoction by HPLC-ESI-MS/MS. J. Pharm. Biomed. Anal. 2011, 56, 1046-1056. [CrossRef] [PubMed]

23. Zhang, X.; Wu, J.; Han, Z.; Mei, W.L.; Dai, H.F. Antioxidant and Cytotoxic Phenolic Compounds of Areca Nut (Areca catechu). Chem. Res. Chin. Univ. 2010, 26, 161-164.

24. Jahns, E. Ueber die Alkaloïde der Arecanuss. Berichte Der Deutschen Chemischen Gesellschaft 2006, 21, 3404-3409. [CrossRef]

25. Baruah, H.K. Arecanut, Indias popular masticatory Botany, chemistry and utilization. Econ. Bot. 1958, 12, 315-345.

26. Huang, J.L.; Mcleish, M.J. High-performance liquid chromatographic determination of the alkaloids in betel nut. J. Chromatogr. A 1989, 475, 447-450. [CrossRef]

27. Yang, W.Q.; Wang, H.C.; Wang, W.J.; Wang, Y.; Zhang, X.Q.; Ye, W.C. Chemical constituents from the fruits of Areca catechu. J. Chin. Med. Mater. 2012, 35, 400-403.

28. Shoji, T.; Mutsuga, M.; Nakamura, T.; Kanda, T.; Akiyama, H.; Goda, Y. Isolation and structural elucidation of some procyanidins from apple by low-temperature nuclear magnetic resonance. J. Agric. Food Chem. 2003, 51, 3806-3813. [CrossRef] [PubMed] 
29. Stalmach, A.; Troufflard, S.; Serafini, M.; Crozier, A. Absorption, metabolism and excretion of Choladi green tea flavan-3-ols by humans. Mol. Nutr. Food Res. 2009, 53, S44-S53. [CrossRef] [PubMed]

30. Giri, S.; Idle, J.R.; Chen, C.; Zabriskie, T.M.; Krausz, K.W.; Gonzalez, F.J. A metabolomic approach to the metabolism of the areca nut alkaloids arecoline and arecaidine in the mouse. Chem. Res. Toxicol. 2006, 19, 818-827. [CrossRef] [PubMed]

Sample Availability: Samples of the compounds are not available from the authors.

(C) 2017 by the authors. Licensee MDPI, Basel, Switzerland. This article is an open access article distributed under the terms and conditions of the Creative Commons Attribution (CC BY) license (http://creativecommons.org/licenses/by/4.0/). 